História Política 



\title{
A questão da evolução da cidadania política no Brasil
}

\author{
DÉCIO AZEVEDO MARQUES DE SAES
}

$\mathrm{N}$

O PERíodo recente - e especialmente desde a entrada em vigor da Constituição Federal de 1988 -, a configuração da cidadania política no Brasil tem sido um dos temas preferenciais de politólogos e constitucionalistas. Arrisco-me a abordá-lo ainda uma vez. Meu objetivo, entretanto, não é o de apresentar um quadro morfológico da evolução da cidadania política no Brasil. O mapeamento dos seus estágios sucessivos tem sido realizado, com maior ou menor grau de minúcia, por inúmeros cientistas sociais, historiadores e juristas. Os livros, ensaios e artigos produzidos por esses autores têm tornado a marcha dos direitos políticos no Brasil - nos seus sucessivos avanços e recuos - razoavelmente conhecida pelo público interessado na história contemporânea do Brasil. Por isso, lançar-me num trabalho dominantemente descritivo não teria muito sentido do ponto de vista acadêmico. Esse trabalho seria, além do mais, monótono para o público leitor, que seguramente já passou os olhos por inúmeras listagens das carências do Brasil no plano da cidadania política:

- interdição do voto do analfabeto, desde a lei imperial de 1881 até a Constituição Federal de 1988;

- ausência do voto feminino, do voto secreto e de uma Justiça eleitoral de cunho burocrático e profissional, até o Código eleitoral de 1932 e a Constituição Federal de 1934;

- limitação prática do exercício do direito de voto durante toda a Primeira República, por obra da submissão da maioria do eleitorado a práticas coronelísticas;

- crescimento constante, desde a redemocratização do regime político em 1945, do clientelismo urbano, como instrumento de deformação das vontades no plano eleitoral;

- supressão total (no caso do Estado Novo) ou quase total (no caso do regime militar) dos direitos políticos etc.

Tentaremos aqui, portanto, realizar um outro tipo de trabalho. Mais precisamente, envolver-nos-emos na busca de uma explicação para a configuração assumida, no Brasil, pelo processo de evolução da cidadania política. Se vale a pena incursionar nesse terreno, é porque poucos estudiosos propõem a esse respeito 
hipóteses suficientemente explícitas, sistemáticas e desenvolvidas. Dentre os autores que se mostram visivelmente conscientes de não ser possível passar pelo tema da evolução da cidadania em geral ou da cidadania especificamente política no Brasil sem que se reflita minimamente sobre as causas históricas da emergência de um certo padrão evolutivo, destacam-se José Murilo de Carvalho, com seu livro Desenvolvimiento de la ciudadania en Brasil(1) e Luiz Carlos Bresser Pereira, com seu artigo Cidadania e res publica: a emergência dos direitos republicanos (2). A “consciência teórica” desses autores torna os seus textos liminarmente superiores aos trabalhos de orientação empirista, que só involuntária ou inadvertidamente acabam incursionando no terreno das hipóteses explicativas (e, se o fazem, é porque, do ponto de vista do próprio leitor médio, há uma questão que não pode ser contornada por nenhum especialista: qual seria a razão histórica de um tal déficit de cidadania, de uma tal carência de democracia no Brasil?) Se destacamos aqui o trabalho desses dois autores (cujas hipóteses explicativas serão examinadas mais adiante), é porque, desse modo, legitimamos indiretamente a nossa própria investigação acerca das razões históricas da concretização de um certo padrão de evolução da cidadania política no Brasil. Essa investigação implicará, de um lado, a crítica a outras hipóteses explicativas, constantes da bibliografia disponível sobre o tema; de outro lado, a imposição de certos retoques ao mapa da evolução da cidadania política no Brasil. Com relação a esse último ponto, esclareça-se que, se a descoberta de novas hipóteses explicativas não altera, nas suas linhas gerais, o mapa convencional da marcha dos direitos políticos, ela exige que se confira maior relevo a certos aspectos, menos valorizados nas análises dominantemente descritivas; ou que se redimensione outros aspectos, cujo significado só se torna visível à luz do esquema explicativo que se está testando.

\section{O conceito de cidadania política}

Não podemos passar à abordagem do processo histórico brasileiro sem antes apresentar, ainda que de modo relativamente sumário, o nosso conceito de cidadania política (3). Nossa perspectiva, no estabelecimento de uma definição operacional, é a da revisão crítica do conceito liberal contemporâneo - vale dizer, marshalliano - de cidadania política. Para Marshall, a cidadania política na sociedade industrial moderna ou contemporânea (nós diríamos, sociedade burguesa ou capitalista) designa a participação do Povo - isto é, dos indivíduos que o compõem - no exercício do poder político. Tal participação concretiza-se, segundo Marshall, como exercício efetivo, por parte do Povo, do direito de escolher os seus governantes. E o exercício efetivo desse direito implica, de um lado, a existência de um processo eleitoral autêntico, supervisionado por instituições judiciárias independentes, que garantam a correspondência entre o resultados das eleições e a vontade eleitoral da maioria social; de outro lado, a existência de governantes que de fato governem, o que supõe a presença de um Parlamento forte, efetivamente participante na tomada das grandes decisões nacionais. 
A rigor, a definição apresentada indica que Marshall se submete ao mito contemporâneo da cidadania, ao invés de propor - como seria de se esperar de um cientista político - instrumentos conceituais utilizáveis na crítica desse mito. A "participação do Povo no exercício do poder político" é, mais que uma realidade ou uma possibilidade, uma magnífica alegoria, que reproduz o princípio de funcionamento reivindicado e proclamado porém não cumprido pelas instituições políticas capitalistas. Ou por outra: essa fórmula traduz um ideal político, mas não se presta à caracterização do funcionamento real do Estado capitalista. Os limites desse funcionamento são entrevistos até mesmo por um autor conservador como Gaetano Mosca. Nos seus Elementi di scienza politica, a cidadania política contemporânea se reduz, na melhor das hipóteses, ao exercício, por parte das massas, de uma influência periférica e marginal sobre os agentes tomadores das macrodecisões políticas. Mesmo no sistema político mais democrático, tal influência só pode ser, segundo Mosca, periférica e marginal, já que as macrodecisões políticas estão concentradas nas mãos de uma elite política ou classe governante. Dessa formulação de Mosca, poderíamos - descontadas as diferenças teóricas - aproveitar a idéia de que o exercício da cidadania política pelas massas é insuscetível de revolucionar a natureza do poder político dentro da sociedade capitalista. Mas, se assim é, coloca-se inevitavelmente a seguinte pergunta: a cidadania política não seria uma ilusão, pelo menos dentro dos limites da sociedade capitalista?

Na verdade, não há como responder de um modo simples e unívoco a essa questão. A estrutura econômica capitalista - vale dizer, a relação entre capital e trabalho assalariado - não pode se reproduzir numa sociedade qualquer, se nela não tiver se implantado previamente a forma-sujeito de direito. Essa forma, em sua versão elementar, corresponde ao reconhecimento, por parte do Estado, de que todos os agentes da produção - proprietários dos meios de produção ou trabalhadores - são sujeitos individuais de alguns direitos essenciais, sem os quais não se pode celebrar contratos de trabalho (isto é, um acordo livre entre vontades individuais) nem portanto chegar à formação de um mercado de trabalho. Tais direitos consistem na liberdade de ir e vir e de manifestar livremente a sua vontade, bem como na capacidade de se apropriar de bens ou de si mesmo e de fazer valer contra terceiros essa capacidade.

A forma-sujeito de direito concretiza-se portanto, em sua versão elementar, em liberdades civis, sem as quais o capitalismo não pode ser implantado. Esses direitos elementares não são ilusórios; eles representam prerrogativas reais, conquistadas a duras penas pelas classes trabalhadoras mediante lutas contra as classes dominantes. Eles adquirem porém, na sua formulação estatal, uma aparência universalista e igualitária, que é ilusória, pois sob a forma da troca de eqüivalentes (salário versus trabalho) assumida pela relação entre capitalista $\mathrm{e}$ trabalho assalariado jaz a desigualdade fundamental entre os despossuídos 
(coagidos pela necessidade material a prestar sobretrabalho) e os proprietários dos meios de produção (que contam com esses recursos materiais para subjugar as vontades dos trabalhadores). Desse modo, a concretização da forma-sujeito de direito mediante a criação de direitos civis implica, de um lado, a corporificação de liberdades que são reais, ainda que sejam desigualmente distribuídas entre as classes sociais (liberdades ou prerrogativas essas que correspondem ao aspecto concreto da cidadania civil). De outro lado, ela produz um efeito ideológico de cidadania; ou seja, o sentimento de que essa concessão de prerrogativas reais igualiza todos os indivíduos, o que irá alimentar no plano social o próprio ideal da igualdade.

Passemos agora à análise da cidadania propriamente política. Ela se configura como um desdobramento secundário e contingente da forma-sujeito de direito na sociedade capitalista. Esta pode se reproduzir, em sua estrutura econômica, sem que se concedam quaisquer direitos políticos às classes trabalhadoras. Para que essa reprodução ocorra, são necessários: no plano econômico, a vigência de liberdades civis que permitam a celebração de contratos de trabalho e a conseqüente emergência de um mercado de trabalho; no plano político, a vigência de qualquer mecanismo de legitimação do Estado capitalista, podendo tal mecanismo ter inclusive um caráter pré-democrático (como a legitimação fundada na competência de uma burocracia oficialmente recrutada segundo princípios universalistas e meritocráticos). Porém, ainda que não corresponda a uma necessidade estrutural do capitalismo, a concessão de direitos políticos às classes trabalhadoras pode ocorrer - conforme o esquema teórico proposto por Göran Therborn (4) -, caso se combinem a pressão das classes trabalhadoras sobre o Estado capitalista e a emergência de conflitos políticos no seio do bloco das classes dominantes.

Como as liberdades civis, as liberdades políticas apresentam um aspecto real: elas tornam possível às classes trabalhadoras exercerem influência periférica e marginal sobre os processos de tomada das macrodecisões, por participação independente na escolha dos governantes. E também produzem, como as liberdades civis, um efeito ideológico: o sentimento generalizado de igualdade política entre todos os membros da nação. Do ponto de vista institucional, é freqüente que a diferença entre o caráter real das prerrogativas reconhecidas pelo Estado capitalista e o seu efeito ideológico sobre o conjunto da sociedade se manifeste como diferença entre dispositivos da legislação constitucional (tendentes a encarnar princípios universalistas e igualitários) e dispositivos da legislação ordinária (tendentes a outorgar prerrogativas diferenciadas a grupos sócio-econômicos diversos: não apenas às classes sociais antagônicas, mas também a camadas de uma mesma classe, a grupos ocupacionais etc.). Foi Hobsbawm quem caracterizou de modo lapidar a tendência à defasagem entre os princípios constitucionais e o âmbito real da legislação ordinária na sociedade capitalista: "Por isso, as Declarações de Direitos foram, na teoria, universalmente aplicáveis. Na verdade, sua 
força maior de atração foi o fato de fornecerem a grupos que reclamam melhores condições para si mesmos por motivos especiais - por exemplo, as mulheres, ou os negros, ou os operários - justificativas universais para fazê-lo, o que torna mais difícil para outras pessoas, que aceitem a idéia desses direitos, resistir à reivindicação em princípio" (5). Agregue-se que é ainda possível a instauração, dentro do próprio texto constitucional de um Estado capitalista, da contradição formal entre universalismo e particularismo, entre igualdade e desigualdade. Isso tende a ocorrer sobretudo em Constituições de caráter analítico, que descem à explicitação da orientação a ser imposta às políticas econômica, social, externa etc. (as Constituições de caráter sintético sendo menos propensas a serem atravessadas por contradições formais).

Até agora, abordamos num plano estritamente teórico a dupla dimensão da forma-sujeito de direito (caráter real das prerrogativas de grupo; e caráter ilusório da igualdade entre todos os indivíduos, proclamada pelo Estado). Pensando agora na concretização da forma-sujeito de direito em formações sociais capitalistas, devemos salientar desde logo que prerrogativas civis ou políticas, reconhecidas por um Estado capitalista concreto, também podem ser ilusórias, caso permaneçam "no papel" e não sejam cumpridas na vida real. Muitos pequenos países apresentam-se, do ponto de vista dos textos jurídicos, como "paraísos de direitos", quando na verdade nem a Constituição nem o próprio Código Civil são respeitados na prática. Essa é evidentemente uma situação extrema, em que pode viver por muito tempo algum país situado na periferia do sistema capitalista mundial. Ela não pode portanto ser confundida com situações qualitativamente distintas, que correspondem na verdade a fases por que passam, necessariamente, todas as formações sociais capitalistas. A dinâmica política que envolve o Estado capitalista e as classes trabalhadoras contempla uma fase em que o aparelho de Estado, sob a pressão popular, declara novos direitos (civis ou políticos).

A seguir, apoiados nessa declaração, certos segmentos das classes trabalhadoras, auxiliados por aquela parte da burocracia estatal que é portadora da ideologia jurídica da classe média (o corpo judiciário), procurarão impô-los na prática às classes dominantes. O próprio Marshall o reconhecia: não pode haver concretização de direitos, na sociedade contemporânea, sem luta popular e burocrática pela aplicação concreta da lei, a ausência dessa luta permitindo de resto que se lancem dúvidas sobre a efetividade da dinâmica de instauração e de desenvolvimento da cidadania num país capitalista qualquer. É a presença dessa dinâmica que comprova que certas sociedades capitalistas, mesmo que ainda não tenham chegado à aplicação da lei por toda parte, não são "falsos paraísos do direito", como algumas repúblicas onde o texto constitucional é apenas mais uma das peças do folclore nacional. 
A situação teórica mencionada implica a existência de uma defasagem entre a estrutura econômica (capitalista) e os direitos efetivamente em vigor (desrespeito prático ao texto da legislação sobre contrato de trabalho). Mas tal defasagem não eqüivale a uma contradição; a luta popular e burocrática pela concretização das liberdades civis elementares é inclusive um fator essencial de desenvolvimento do capitalismo, já que ela visa substituir a figura do trabalhador concreto pela capacidade abstrata de trabalho e, desse modo, contribui decisivamente para a transformação da manufatura (forma econômica de transição) em grande indústria moderna. Situação teórica diferente desta é aquela em que a presença, dentro de uma formação social em transição para o capitalismo ou já capitalista, de uma área onde predominam formas econômicas pré-capitalistas determina o bloqueio, no médio ou longo prazos, da expansão dos direitos civis ou políticos já vigentes na área capitalista dessa formação social. Nesta segunda situação teórica, configura-se, diferentemente do que ocorria na primeira, uma contradição entre uma estrutura econômica parcial (pré-capitalista) e os direitos, típicos do modo de produção capitalista, proclamados como válidos no plano nacional. Ilustremos a diferença entre essas duas situações teóricas. De um lado, uma economia urbana que implique a existência de um parque manufatureiro e de um aparelho de prestação de serviços pessoais fornece um patamar material mínimo a partir do qual a forma-sujeito de direito pode ser implantada, integralizando a transformação da economia urbana numa economia capitalista. De outro lado, uma economia agrária estruturada sobre a base de relações de dominação pessoal bloqueia liminarmente o exercício das liberdades civis elementares por parte dos trabalhadores rurais, para não falarmos das liberdades políticas, totalmente desvirtuadas pela extensão, até o campo político-eleitoral, das relações de lealdade pessoal entre proprietário rural e trabalhador. Nessa última situação, só no longo prazo - com a transformação da agricultura por obra de sua subordinação à indústria capitalista - torna-se possível a efetiva penetração dos direitos civis e políticos na área rural em questão.

\section{Algumas hipóteses sobre o padrão brasileiro de evolução da cidadania política}

Podemos agora passar à análise da evolução da cidadania política no Brasil. A realização desse trabalho implica descrever, ainda que minimamente, os diferentes estágios por que passaram os direitos políticos no país, bem como propor alguma explicação para a configuração assumida pelo elenco de direitos políticos em cada subperíodo político da fase republicana. Para chegarmos a um esquema explicativo próprio - o que, como esclarecemos anteriormente, implica impor certos reajustes ao mapa dos direitos políticos no Brasil -, temos de começar fazendo um exame crítico das hipóteses mais relevantes, constantes da bibliografia disponível sobre o tema. 
Em Desenvolvimiento de la ciudadania en Brasil, José Murilo de Carvalho confere um valor praticamente universal à caracterização da evolução da cidadania na sociedade industrial moderna, proposta por Marshall em Cidadania, classe social e status. Analisando a Inglaterra contemporânea, esse autor detectara a concretização, nesse país, de um certo padrão de evolução da cidadania: instauração predominante das liberdades civis elementares no século XVIII; de direitos políticos no século XIX; e de direitos sociais no século XX. Já Carvalho vai mais longe, sustentando que o padrão inglês, desenhado por Marshall, é na verdade o padrão normal de instauração progressiva da cidadania na sociedade contemporânea. Na sua perspectiva, qualquer outro padrão seria anômalo, isto é, representaria um desvio da normalidade com conseqüências funestas sobre aquilo que poderíamos chamar "o resultado final": a situação presente da cidadania, considerada globalmente, numa sociedade qualquer.

Munido desse dispositivo teórico, Carvalho passa à análise política da sociedade brasileira e detecta a presença constante de pelo menos duas grandes anomalias no processo de implantação e de desenvolvimento da cidadania no Brasil. A primeira anomalia consistiria na existência de uma defasagem permanente entre os direitos legalmente declarados e os direitos efetivamente exercidos, ou melhor, numa contradição persistente entre o "país legal" e o "país real". A segunda anomalia consistiria numa inversão constante da ordem normal de implantação de diversos elencos de direitos. Assim, por exemplo, amplas liberdades políticas ter-se-iam instaurado em pleno Império, isso ocorrendo paradoxalmente numa sociedade (escravocrata) que negava liberdades civis elementares a escravos e a homens livres pobres. Além disso, os direitos políticos teriam passado por sucessivos avanços e recuos (o que implicaria a alternância, na história política do Brasil, de períodos democráticos e de períodos ditatoriais). Finalmente, importantes elencos de direitos sociais teriam sido concedidos, a título compensatório, por dois regimes ditatoriais: o Estado Novo e o regime militar de 19641984 (o que significaria uma antecipação anômala da instauração de direitos sociais sobre a de direitos políticos).

Como Carvalho explica tais anomalias (e, repetimos, é um mérito seu o de procurar tal explicação)? Na reflexão sobre as causas históricas desse desvio, o autor recorre em primeira instância ao tema da carência relativa de lutas populares pela conquista de direitos no Brasil; carência essa que se evidenciaria na comparação com o caso inglês, no qual avulta a importância, no processo de conquista de direitos, de movimentos populares como o cartismo, numa primeira etapa, e o trabalhismo organizado em partido político, numa segunda etapa. Porém, é um fator cultural de natureza transhistórica que explica em última instância, segundo Carvalho, não só tal carência de lutas populares pela cidadania como também, de um modo mais geral, as anomalias da implantação e do desenvolvimento da cidadania no Brasil. Esse fator seria a cultura política ibérica: 
ela teria transmitido ao Brasil, desde o início da colonização, um ideal de comunidade paternalista, no qual não há lugar para a luta pela conquista de direitos, substituída esta pela distribuição de favores por parte dos de cima e pela manifestação de lealdade ou gratidão por parte dos de baixo.

O modelo explicativo esboçado por Carvalho coloca, ao leitor minucioso, problemas teóricos que não são de pequena monta: o fator cultural de caráter transhistórico intervém, como uma força externa deformadora, num processo o da emergência e desenvolvimento da cidadania - cujas causas se encontram alhures? Ou ele é a causa geral de um processo anômalo único - o da emergência e desenvolvimento da cidadania -, insuscetível de ser decomposto, para fins explicativos, em aspectos "positivo" (a idéia de direitos) e "negativo" (o desrespeito prático à idéia de direitos)? No caso de a primeira fórmula exprimir mais adequadamente o pensamento de Carvalho, o problema não resolvido é o da caracterização do motor do processo, cujo percurso sofreria um desvio por obra da influência do fator cultural de natureza transhistórica. No caso de a segunda fórmula corresponder mais estreitamente à perspectiva de Carvalho, avultará a incongruência metodológica consistente em buscar a explicação de uma mudança política real (a instauração e o desenvolvimento da cidadania, ainda que com "déficits" e "carências") em elementos invariantes, quando seria mais razoável pesquisar, na busca de alguma relação causal entre processos, variações concomitantes. Em qualquer um dos dois casos, é o modelo culturalista de Carvalho que bloqueia a busca do motor do processo de implantação e de desenvolvimento da cidadania; processo esse que se configura como uma mudança política real, por mais "atípica" e "anômala" que possa ser considerada com relação ao padrão inglês.

Já Luiz Carlos Bresser Pereira busca, em Cidadania e res publica: a emergência dos direitos republicanos, um modelo explicativo que capte a relação causal subjacente a duas variações concomitantes: o desenvolvimento do capitalismo e o processo de instauração de direitos políticos. Para Bresser Pereira, o desenvolvimento do capitalismo ocasiona a desconcentração de quatro atributos que conferem poder aos grupos sociais: a força, a riqueza, a hegemonia ideológica e o conhecimento técnico e organizacional. Ora, essa desconcentração de recursos, engendrada no longo prazo pelo capitalismo, é, segundo o autor, o patamar indispensável à instauração efetiva de direitos políticos e à conseqüente implantação de regimes democráticos. Num outro texto (Sociedade civil: sua democratização para a reforma do Estado) (6), Bresser Pereira parece se servir desse modelo explicativo na análise do processo histórico brasileiro. Para ele, há uma clara defasagem entre a evolução política dos países capitalistas avançados e a de países periféricos, como o Brasil ou outros da América Latina: enquanto os primeiros alcançaram a cidadania política e o regime democrático na primeira metade do século XX, os últimos só chegaram a esse patamar na segunda metade 
do século XX. E essa defasagem no plano do advento da cidadania política e da democracia parece exprimir o atraso dos países periféricos no plano do desenvolvimento do capitalismo.

A reflexão crítica sobre o esquema explicativo sugerido por Bresser Pereira deve começar destacando o seu aspecto positivo: vale dizer, as implicações materialistas de sua postura teórica. Tais implicações conferem à sua análise um interesse superior àquele apresentado por análises fundadas numa postura idealista. A seguir, porém, devemos qualificar como problemática a tese de que o desenvolvimento do capitalismo produz genericamente efeitos desconcentradores. É certo que tal desenvolvimento engendrou um aparelho de serviços e, conseqüentemente, uma nova classe média, em permanente expansão, o que desmentiu a suposição marxiana inicial de uma crescente polarização econômica na sociedade capitalista. Também é incontestável que os ganhos de produtividade, ensejados por esse desenvolvimento, viabilizaram o aumento dos salários reais dos trabalhadores (aumento esse que exprimiria, não a liberalidade da classe capitalista, mas a complexificação crescente da pauta de consumo incorporada ao processo de reprodução da força de trabalho alocada no sistema produtivo capitalista).

Uma vez reconhecidos tais efeitos, deve-se levar em conta que a dinâmica do modo de produção capitalista envolve um processo altamente concentrador: a concentração e a centralização do capital, que determinam a passagem do capitalismo de sua fase concorrencial para a sua fase monopolista e se mantêm inclusive na fase atual, ainda que ocultas sob formas institucionais descentralizadoras (por exemplo, empresas com autonomia jurídica, mas estratégica e organizacionalmente dependentes do capital financeiro). Ora, esse processo econômico, como já foi apontado por Marx em $O$ Capital (7), implica também a concentração espacial da indústria e o fim da dispersão das unidades fabris (que inicialmente tendiam a se localizar no campo, por serem metamorfoses das velhas manufaturas rurais). A concentração espacial do aparelho produtivo capitalista cria, por sua vez, condições mais favoráveis à emergência, no seio das classes trabalhadoras, de um movimento reivindicativo e político numericamente mais extenso e organizativamente mais poderoso. Há portanto um ângulo do processo de desenvolvimento do capitalismo que não foi explorado por Bresser Pereira: a concentração e a centralização do capital têm como subproduto o aumento da capacidade de pressão das classes trabalhadoras sobre o Estado, o que pode redundar na conquista de direitos. Existe assim uma relação tendencialmente positiva - mas que não se concretiza sempre, como nos mostraram o nazismo e o fascismo - entre a concentração/centralização do capital e a conquista de direitos políticos.

Essa observação sobre as implicações políticas de um aspecto da dinâmica do modo de produção capitalista abre caminho para a proposição de uma fórmula teórica geral sobre a evolução da cidadania política nas formações sociais 
capitalistas. Tal evolução relaciona-se com o padrão de desenvolvimento do capitalismo, no sentido amplo da expressão (abrangendo tanto o processo de transição para o capitalismo quanto o processo de reprodução ampliada do capitalismo), que se concretiza numa formação social determinada. Mais precisamente, a evolução da cidadania política é parte do processo de desenvolvimento do capitalismo numa formação social, e isso num duplo sentido: ela é influenciada pela dimensão especificamente econômica desse processo, mas, por sua vez, também exerce influência sobre a mesma. A evolução interna de um sistema econômico pré-capitalista - evolução essa que pode envolver, por exemplo, a mercantilização crescente da produção, o aumento da produtividade e a intensificação da pressão sobre o produtor direto com vistas à obtenção de mais renda - acirra antagonismos sociais que acabarão por colocar em crise o Estado pré-burguês. A configuração específica desse processo evolutivo pode determinar, ou não, uma radicalização da luta popular pela instauração do Estado "republicano" (burguês) até a incorporação da bandeira da "democracia" (caso em que a luta pelas liberdades civis elementares se desdobra em luta pela instauração da cidadania propriamente política). Também dependem de tal configuração o nível de diferenciação interna das classes dominantes e, conseqüentemente, a intensidade do conflito político no seio do bloco das classes dominantes, conflito esse que influencia a amplitude da luta popular - "republicana" tout cout ou "republicano-democrática" - contra o Estado pré-burguês. Inversamente, o resultado político final de tais conflitos e lutas - advento de uma democracia representativa ou de uma ditadura republicana -, por ser decisivo para a definição da hegemonia política no seio do bloco no poder (8), delineia-se como um dos fatores que influenciam o curso da transição para o capitalismo, já que o avanço desse processo depende da capacidade hegemônica das diferentes classes ou frações dominantes (por exemplo, os obstáculos ao avanço da grande indústria moderna e à subordinação da agricultura à indústria, numa formação social em processo de transição, não poderão ser superados caso não seja destruída a capacidade da burguesia mercantil agroexportadora de colocar o aparelho de Estado a serviço dos seus interesses econômicos de fração).

Já a dinâmica interna de um sistema econômico capitalista assume mais cabalmente a forma marxista clássica do desenvolvimento das forças produtivas (concentração e centralização crescentes do capital, interdependência crescente das atividades econômicas). Tal desenvolvimento contribui para a constituição dos trabalhadores assalariados, previamente atomizados por força de sua inserção na esfera da circulação (mercado de trabalho), como coletivo capaz, no mínimo, de pressionar o Estado capitalista pelo reconhecimento de sua existência, ou, no máximo (especialmente no caso de se configurar uma situação revolucionária, ou seja, uma crise social e política aguda), de se organizar tendo em vista a derrubada da ordem social capitalista. 
Desnecessário dizer que o desenvolvimento das forças produtivas numa formação social capitalista acirra os conflitos políticos no seio das classes dominantes (por exemplo, o conflito entre capital monopolista e médio capital, ou entre capital bancário e propriedade fundiária); e que tais conflitos abrirão espaço para a luta popular pela instauração e ampliação da cidadania política. Inversamente, a trajetória das lutas populares pela conquista de direitos políticos e o percurso dos conflitos políticos no seio das classes dominantes exercerão uma influência decisiva sobre o curso do desenvolvimento capitalista (política intervencionista e keynesiana ou política neoliberal? Ação estatal de ampliação prioritária do mercado interno ou de incentivo prioritário às exportações?) na formação social em questão. Também neste caso atua como elemento mediador entre os dois processos a configuração da hegemonia política no seio do bloco no poder, já que, por um lado, ela é o efeito do entrecruzamento de lutas populares e de conflitos intraburgueses e, por outro, contribui para acelerar, retardar ou desviar o curso do desenvolvimento capitalista numa formação social.

É este esquema teórico que pretendemos testar na análise da evolução da cidadania política no Brasil. O leitor perceberá facilmente que os termos de sua formulação são bastante gerais. Esse procedimento generalizante resultou de uma certa cautela metodológica. Já que ainda não nos acodem todos os conhecimentos teóricos necessários à especificação dos diversos mecanismos causais evocados, preferimos conferir às nossas formulações um caráter "aberto". Desse modo, a pesquisa histórica, ao invés de ser proposta e apresentada como mera confirmação de um esquema teórico totalmente fechado, terá um papel positivo a cumprir no enriquecimento de nossas hipóteses explicativas (o que não se fará de modo imediato: o desenvolvimento teórico é um processo bem mais lento que o da produção de um único texto).

\section{Um breve quadro morfológico da evolução da cidadania política no Brasil}

Uma vez estabelecido que o nosso objetivo principal neste texto é a busca das causas históricas da concretização de um certo padrão de evolução da cidadania política no Brasil, devemos apresentar, como ponto de partida, uma síntese das características morfológicas desse processo evolutivo. Tais características são, basicamente, duas. Em primeiro lugar, os direitos políticos instaurados no Brasil entre 1891 e 1988 apresentaram, em fases sucessivas, limitações especificas, não similares às limitações apresentadas, também em fases sucessivas, pelos direitos políticos instaurados nos países capitalistas centrais. Para que todas as implicações da enunciação dessa característica possam ser apreendidas pelo leitor, impõem-se dois esclarecimentos. Quando aludimos a limitações impostas aos direitos políticos numa formação social capitalista 
qualquer, não estamos nos referindo a eventuais obstáculos ao exercício efetivo do Poder político pela maioria social, pois, como procuramos indicar anteriormente, seria esperar demais da cidadania política supor que ela pudesse ser o instrumento institucional da instauração do Poder político da maioria social no quadro de uma sociedade capitalista.

Tais limitações têm portanto um caráter mais modesto: elas consistem antes em obstáculos ao exercício, por parte da maioria social, de uma influência meramente marginal ou periférica sobre o processo de tomada das macrodecisões políticas (influência essa que, obviamente, é relevante para a definição da situação das classes trabalhadoras dentro da sociedade capitalista, embora não o seja para a caracterização sociológica da natureza de classe do Poder político atuante nesse tipo de sociedade). À luz desse primeiro esclarecimento, convém advertir que, mesmo no sentido modesto apontado, limitações aos direitos políticos não são peculiaridades dos países capitalistas periféricos; elas também pontilham a história política dos países capitalistas centrais. Caberia portanto à análise política comparada estabelecer as especificidades dos dois blocos de países capitalistas - centrais e periféricos - nesse terreno. Esse trabalho seria de grande utilidade para o pesquisador empenhado em estabelecer a combinação de limitações aos direitos políticos presente, em fases sucessivas, numa formação social capitalista determinada, central ou periférica.

Prossigamos na apresentação da primeira característica morfológica da evolução da cidadania política no Brasil. As limitações aos direitos políticos aqui concretizadas, em fases sucessivas, entre 1891 e 1988 resultaram da combinação de limitações presentes desde logo no plano das definições constitucional e legal dos direitos políticos com limitações impostas ao exercício de direitos políticos já declarados. A natureza dessa combinação de limitações aos direitos políticos será esclarecida mais adiante.

Passemos agora à enunciação da segunda característica morfológica da evolução da cidadania política no Brasil. Esta, além de ter apresentado limitações de caráter específico, foi, no período em questão (1891-1988), instável e intermitente. Tal característica distancia o Brasil de países onde a instauração da cidadania se delineou, após uma ruptura institucional radical (a "revolução política burguesa"), como um longo processo evolutivo, sem recuos ou sobressaltos (o que não quer dizer, sem lutas sociais), como a Inglaterra ou alguns países da Europa do Norte.

Deveremos, a seguir, reapresentar de modo mais detalhado essas duas características morfológicas e, quase concomitantemente, propor alguma reflexão sobre as causas históricas da concretização desse padrão de evolução da cidadania política no Brasil. 


\section{As limitações da cidadania política na Primeira República brasileira (1889-1930)}

O ponto de partida para a instauração da cidadania, civil e política, no Brasil é a Revolução política burguesa, que, entre 1888 (Abolição da escravidão) e 1891 (proclamação da Constituição republicana), subverteu o sistema jurídico, instaurando a forma-sujeito de direito em sua versão elementar (o que significa o reconhecimento estatal de todos os agentes da produção, independentemente de sua posição na estrutura econômica - proprietário dos meios de produção, trabalhador - como sujeitos individuais de direitos). Seria inviável a concretização da cidadania, civil ou política, na sociedade escravista imperial, dada a total incompatibilidade da forma-sujeito de direito com qualquer modo de produção escravista, antigo ou moderno. Os escravos eram considerados como "coisas" pelo direito escravista: e portanto estavam excluídos, por definição, da categoria dos sujeitos individuais de direitos. Conseqüentemente, a forma universalista e igualitária dos direitos individuais jamais poderia se impor numa sociedade escravista. Tinham razão portanto os abolicionistas e os republicanos radicais, quando sustentavam que, no Brasil imperial, não havia direitos; apenas privilégios (vale dizer, prerrogativas enunciadas em termos particularistas, pois formalmente reservadas aos integrantes da ordem dos homens livres).

Na perspectiva teórica aqui adotada, não haveria como aceitar a conclusão que José Murilo de Carvalho, na obra já citada, tira da análise de dados referentes à evolução da participação eleitoral no Brasil. Carvalho lembra que, na década de 1870 (isto é, antes da reforma eleitoral de cunho restritivo concretizada através da Lei de 1881 ), a participação eleitoral chegara a $11 \%$ da população total (o que eqüivalia a $13 \%$ da população livre), para depois descer a $2,2 \%$, em plena fase inicial do período republicano (1894). Da análise desses dados eleitorais, Carvalho tira a conclusão de que, na passagem do Império à República (isto é, de um Estado escravista a um Estado burguês moderno), teria ocorrido uma considerável regressão no plano da cidadania política. Mais especificamente, a abolição, com a proclamação da República, dos critérios censitários de definição da amplitude do eleitorado não teria sido suficiente para compensar a limitação da população eleitoral resultante da confirmação, na Constituição federal de 1891, da interdição do voto dos analfabetos (introduzida pela Lei de 1881).

Alguém poderia sustentar que, uma vez descontadas as diferenças terminológicas (que fazem Carvalho detectar a presença de direitos ali onde vemos apenas privilégios), poderíamos nos render às evidências proporcionadas pelos dados quantitativos eleitorais e concluir, com Carvalho, que teria havido de fato uma regressão política na passagem do Império à República. Ocorre entretanto que, de um ponto de vista substantivo, o aspecto central do processo político imperial era a exclusão eleitoral da classe explorada fundamental (os escravos de latifúndio), 
o que significava a ilegitimidade da incorporação dos seus interesses ao processo decisório imperial. Ora, foi justamente porque a classe explorada fundamental estava excluída oficial e explicitamente da comunidade política que se poderia (inclusive, se deveria) estender a participação efetiva das classes sociais em princípio admitidas na comunidade política; vale dizer, as diversas classes sociais filiadas à ordem dos homens livres. Assim, não houve casualidade alguma na aparente regressão política apontada por Carvalho; portanto, essa diminuição relativa da participação eleitoral, na passagem do Império à República, não deveria ser tratada como mais uma anomalia do processo político brasileiro. Na passagem de um Estado escravista, na qual os agentes político-institucionais eram apenas os proprietários de escravos e os seus aliados, a um Estado burguês moderno, em que todo indivíduo nascido no território nacional era declarado cidadão, seria previsível que se implantassem mecanismos de limitação da participação política efetiva. E isto porque qualquer eventual extensão da participação política provocavaria não apenas incômodos operacionais ou cisões políticas no seio das classes dominantes como também o perigo da subversão, por via institucional, da ordem social vigente.

Feitas essas observações preliminares - cujo objetivo principal foi o de caracterizar como um anacronismo a busca da cidadania política na sociedade escravista imperial - impõe-se a reflexão sobre a seguinte questão: por que a cidadania política emergiu, logo após a Revolução política burguesa de 18881891, por uma declaração constitucional de direitos políticos que parece conter simultaneamente aspectos "avançados" (como o sufrágio masculino adulto sem restrições censitárias) e aspectos "atrasados" (como a interdição do voto do analfabeto)? (9). Ou por outra, qual foi a causa histórica da subordinação da cidadania política a essa configuração específica, por ocasião do nascimento da República? Pondo em operação o nosso método de análise (apresentado anteriormente como um dispositivo teórico adequado a este trabalho), diremos que essa combinação republicana entre a proclamação do princípio do sufrágio universal e a adoção de restrições eleitorais de cunho meritocrático (como a interdição do voto do analfabeto) ou sexual (como a não-proclamação oficial e explícita da legitimidade do voto feminino) deveria ser encarada como o resultado do entrecruzamento, na Revolução política burguesa de 1888-1891, de dois projetos políticos de classe. De um lado, exprimia-se nesse resultado institucional o projeto radical de cidadania política defendido por um segmento - o liberaldemocrático - da classe média abolicionista e republicana, cuja ação política foi uma garantia contra toda eventual tentativa de imposição de um sistema eleitoral censitário ao Estado burguês nascente, como ocorrera em praticamente todos os países capitalistas europeus. De outro lado, também se refletia em nossa primeira declaração constitucional de direitos políticos o projeto do segmento mais organizado e poderoso da classe dominante pós-imperial - a burguesia mercantil-exportadora -, em luta pela conquista da hegemonia política no seio 
das classes dominantes. Como a classe média revolucionária, essa fração burguesa se dispensava de propor restrições censitárias ao voto. Não foram contudo inclinações democráticas radicais que a levaram a essa posição, mas a sua disposição de controlar e manipular o voto do campesinato dependente por intermédio dos proprietários fundiários, colocando desse modo o vasto eleitorado rural a serviço de seu projeto de exercício da hegemonia política.

A emergência de tais projetos políticos de classe resultou, por sua vez, da evolução interna do sistema econômico pré-capitalista - mais especificamente, escravista moderno - vigente no Brasil imperial. Com a entrada do café brasileiro no mercado internacional, o caráter mercantil da economia agrária imperial se estabilizou e se regularizou na região Centro-Sul, o que viabilizou um duplo progresso na diferenciação interna do sistema de classes sociais: a emergência de uma classe média economicamente separada das classes dominantes (por exemplo, profissionais liberais, empregados de escritórios ou jornalistas que viveram, então, basicamente do seu ofício) e a consolidação de uma burguesia mercantil-exportadora economicamente destacada da classe fundiária (entre outros, os "comissários" e as casas exportadoras). Assim, o "movimento da economia" fez com que também se pusesse em movimento o sistema de classes sociais, no qual se enraizaram os novos projetos políticos.

Os dois projetos políticos mencionados coexistiram em equilíbrio instável no governo republicano provisório, mas já se encontrando claramente dissociados por ocasião das primeiras eleições republicanas (as eleições de 15 de setembro de 1890 para a Assembléia Nacional Constituinte). Nestas, o projeto republicano radical - a conversão de todos os indivíduos, independentemente de sua condição sócio-econômica, em verdadeiros cidadãos - da classe média liberal-democrática foi derrotado pelas chamadas "oligarquias"; vale dizer, pela aliança entre proprietários fundiários e burguesia mercantil-exportadora, sob a direção desta (10). E mesmo a ditadura militar implantada por Floriano Peixoto - de resto, rapidamente derrubada pelas "oligarquias" - não pode trazer qualquer auxílio a tal projeto, já que o grupo militar representava politicamente, nessa conjuntura, as tendências nacionalistas e antiliberais de um outro segmento ideológico da classe média. No novo quadro institucional - republicano, democrático-representativo e presidencialista -, as eleições, no seu conjunto, continuavam a ser estritamente controladas pela classe fundiária (agindo, estas, a serviço da hegemonia política da burguesia mercantil-exportadora). Ora, a constante manipulação eleitoral das massas rurais representou a frustração do projeto republicano radical de atribuir a todos os indivíduos a prerrogativa real de escolher, com toda independência e liberdade, os seus governantes.

Quando evocamos a derrota política da classe média defensora de uma liberal-democracia radical e autêntica perante as classes dominantes, após a Abolição e a Proclamação da República, damo-nos conta de que, na Primeira 
República, as principais limitações impostas à cidadania política não decorreram fundamentalmente do caráter limitado da declaração constitucional de direitos políticos, que proscrevia o voto do analfabeto. Tais limitações decorreram principalmente do fato de o exercício do direito de voto estar globalmente controlado pelas classes dominantes politicamente aliadas: a propriedade fundiária (elemento subalterno da aliança) e a burguesia mercantil-exportadora (elemento dominante da aliança). A ausência de uma justiça eleitoral independente e profissional, na República recém-instaurada, não deveria ser encarada como uma falha técnica das novas instituições políticas ou como um indício do atraso cultural e civilizacional do Brasil pós-escravista. Na verdade, tal ausência foi uma expressão da derrota política da classe média liberal-democrática, portadora de ideais meritocráticos e igualitários à luz dos quais a existência desse tipo de instituição só poderia parecer obrigatória.

Sabe-se que, ao invés da justiça eleitoral, instaurou-se um rígido controle do exercício do direito de voto por parte das classes dominantes, e isso em vários níveis. Primeiro nível, o do controle do voto da população rural - composta majoritariamente de camponeses dependentes - por parte dos proprietários fundiários, noutras palavras, o da manipulação do voto das massas eleitorais pelos coronéis (manipulação essa tecnicamente viável, dada a ausência, no plano constitucional, do princípio do voto secreto, e graças à presença de uma legislação ordinária - como a Lei Rosa e Silva, de 1904 - autorizando o voto a descoberto). Segundo nível, o do controle do processo eleitoral pelos chefes políticos locais a serviço da aliança entre propriedade fundiária e burguesia comercial-exportadora, controle esse que se realizava por meio das mesas eleitorais, dotadas de poderes discricionários (como o de fazer os mortos, os analfabetos e os ausentes votarem) e estritamente submissas às chefias políticas locais. Terceiro nível, o do controle do resultado eleitoral pelo processo de qualificação dos eleitos - a chamada "verificação de poderes" -, institucionalmente atribuído ao poder legislativo em todos os níveis e politicamente controlado pela corrente majoritária em cada uma dessas casas legislativas.

Nunca é demais insistir sobre a relação existente entre esse estado da cidadania política - ou seja, essa combinação específica de uma determinada limitação constitucional do direito de voto com um certo tipo de limitação de fato do exercício do direito de voto - com o processo de desenvolvimento do capitalismo no Brasil; ou, mais diretamente, com as especificidades da fase inicial do processo de transição para o capitalismo na formação social brasileira. A regularização e a estabilização do desenvolvimento da economia escravista mercantil, em meados do século XIX, incentivaram a urbanização e a extensão do aparelho de Estado imperial, do que resultou o surgimento de uma classe média envolvida na luta pela cidadania, encarada esta como o caminho para a valorização dos trabalhadores não-manuais perante as classes dominantes. Esse 
processo de desenvolvimento não desaguou porém numa Revolução agrária, que poderia ter viabilizado uma aliança entre campesinato dependente e movimento abolicionista-republicano urbano. E se isso não ocorreu, foi porque, numa economia cujo eixo dinâmico era o setor escravista mercantil, o campesinato dependente só poderia desempenhar um papel político secundário, diferentemente do que ocorreu nas formações sociais feudais em crise. Essas características do processo histórico brasileiro explicaram a feição peculiar do processo de formação da cidadania política no curso da Revolução política burguesa de 18881891. De um lado, a classe média urbana, que dirigia o processo de destruição da ordem social escravista e do Estado escravista imperial, tendia, na moldagem da cidadania política republicana, a rejeitar qualquer restrição censitária (que lhe parecesse ser uma exigência plutocrática e que objetivamente se chocasse com a sua disposição a valorizar o trabalho, ainda que sob a forma de trabalho intelectual, diante da propriedade), aceitando em compensação a adoção de uma restrição de tipo capacitário (a exclusão política do analfabeto, que se coadunava com a sua ideologia meritocrática). De outro lado, as classes dominantes ligadas à agricultura de exportação poderiam, num contexto histórico marcado pela ausência de revolução agrária e, conseqüentemente, pela inexistência em escala nacional de um extenso campesinato independente, aceitar o sufrágio masculino adulto desguarnecido de restrições censitárias, já que estavam conscientes de que seriam as massas rurais, estritamente enquadradas pelos coronéis, o seu grande trunfo eleitoral.

Uma proposta de democracia censitária e de cidadania política limitada, à moda da Europa ocidental do século XIX e do início do século XX, só poderia partir, na Primeira República brasileira, de uma corrente política burguesa de caráter progressista, representativa de uma burguesia industrial com vocação nacionalista. Uma fração burguesa com essas características poderia defender o alijamento eleitoral das massas rurais, por vê-las como um instrumento inconsciente das "oligarquias"; e se engajar numa proposta de redução do contingente eleitoral total ao eleitorado urbano (classe média, operariado, trabalhadores dos serviços), suscetível de ser mobilizado por uma proposta de desenvolvimento nacional alternativo. Como a burguesia industrial nascente esteve longe de revelar essa vocação e de assumir essa posição, as propostas de instauração de um sistema eleitoral censitário, como a de Rodrigues Alves em 1913, ou a de Monteiro Lobato em 1924, revelaram-se, para usar uma expressão de Gramsci, inorgánicas do ponto de vista de sua representatividade de classe.

O retorno a um sistema eleitoral censitário - que já havia vigorado no Império - era portanto improvável, dado que tal proposta não integrava nenhum projeto político de classe. Teoricamente, outras reações à configuração assumida pela cidadania política republicana eram possíveis. Advirta-se entretanto que seria infrutífero buscar propostas estritas de superação das limitações aí vigentes 
na ação das massas rurais ou do operariado urbano. Os camponeses sem terra, amarrados aos proprietários fundiários por relações de dependência pessoal e enquadrados ideologicamente pelo dever de lealdade pessoal para com o seu senhor, funcionavam apenas, conforme a inspirada fórmula de Virgínio Santa Rosa, como "o gigantesco tacape com que os caciques rurais inutilizavam os esforços em prol da melhoria das classes médias" (11). Já o operariado de cidades como São Paulo ou Rio de Janeiro estava altamente impregnado por idéias anarquistas, tendendo portanto a rejeitar a política em geral e o relacionamento com o Estado em particular. Nesse quadro político particular, dificilmente a resistência fabril à exploração capitalista do trabalho poderia se prolongar na luta pelo reconhecimento estatal de direitos propriamente políticos. Na verdade, o grande agente político da crítica à configuração assumida pela cidadania política na Primeira República foi a classe média urbana, ou, mais especificamente, o segmento liberal-democrático dessa classe social, decepcionado com a rápida conversão da República democrática, anunciada na Constituição Federal de 1891, num regime "oligárquico".

Quando levamos em conta a multiplicidade de movimentos que, de uma ou de outra forma, representaram politicamente a classe média urbana - ligas cívicas, movimento tenentista etc. -, poderíamos concluir que tal crítica assumiu dois caminhos ideológicos diversos. De um lado, delineou-se o caminho da denúncia às limitações de fato do exercício do direito de voto (coronelismo, controle do processo eleitoral pelas "oligarquias" etc.), seguida coerentemente pela proposta de instauração da justiça eleitoral e do voto secreto. De outro lado, abriu-se o caminho da denúncia ao sufrágio universal como uma ilusão encenada por partidos políticos oligárquicos, seguida de modo conseqüente pela defesa da instauração da representação de classe ou profissional (substituição do tipo liberal de cidadania política por um novo tipo, de caráter “orgânico”). Nos dois caminhos ideológicos, era cabível a proposta de ampliação da declaração constitucional dos direitos políticos, no sentido da extensão do direito de voto à mulher, isto porque, nos anos 20 , a mulher-trabalhadora de classe média já era uma realidade, estando presente em bancos, escritórios, repartições públicas etc.

\section{O período 1930-1964:}

\section{crise, destruição e restauração da cidadania política}

Analisemos agora a configuração assumida pela cidadania política no período 1930-1964. O título acima sugere, de um lado, que o período em questão apresentou uma certa unidade política, e, de outro, que dentro desse período, a cidadania política passou por diferentes estágios. Se tais estágios são, todos eles, examinados num mesmo item, é porque se deve relacioná-los, um a um, com as características assumidas pelo processo de transição para o capitalismo no período 1930-1964. 
A revolução de 1930 teve como força dirigente um segmento da classe média urbana, o que explica que ela tenha chegado a resultados que não eram desejados por nenhuma fração de classe dominante: a perda, por parte do capital mercantil-exportador, do controle sobre o aparelho de Estado central; a conversão da burocracia estatal civil e militar, descompromissada com relação à tese da "vocação agrícola do Brasil" e defensora de um projeto de industrialização relacionado com a afirmação da soberania nacional, em força política independente. Tais resultados corporificaram, no período 1930-1964, o que se convencionou chamar uma "crise de hegemonia" no seio do bloco das classes dominantes. A expressão “crise de hegemonia" não indica, aqui, a ocorrência de reviravoltas constantes durante o período em questão, no terreno da definição dos objetivos a serem perseguidos pela política econômica e social de Estado. Ela sugere sobretudo que nenhuma fração da classe dominante - propriedade fundiária, burguesia mercantil-exportadora, capital bancário, burguesia industrial - poderia de fato se identificar com a orientação geral assumida pela política de Estado a partir da revolução de 1930.

Em que consistiu essa orientação? De um lado, ela representou o fim do atendimento prioritário aos interesses do comércio de exportação de produtos agrícolas; de outro, implicou o estabelecimento de proteção cambial para a importação de meios de produção, bem como a realização de investimentos em setores essenciais ao crescimento industrial. Se podemos, ainda assim, falar de "crise de hegemonia", é porque a burguesia industrial brasileira, pelo seu caráter duplamente dependente - isto é, dependente diante do capital mercantilexportador que lhe propiciava divisas para importar máquinas, e diante dos países capitalistas centrais que lhe forneciam uma tecnologia industrial avançada - não poderia se reconhecer numa política estatal antecipadora, voltada para a conquista da independência econômica e para a formação de uma verdadeira burguesia nacional. Não se identificando, pelas razões objetivas apontadas, com o papel que a burocracia estatal pós-30 procurava lhe impor, a burguesia industrial brasileira se revestiu nesse período das características de uma burguesia interna, mais que daquelas próprias a uma burguesia nacional (12). Assumindo a condição de burguesia interna, o empresariado industrial brasileiro tendeu, no período 1930-1964, a oscilar politicamente, deixando de prestar um apoio claro, explícito e vigoroso à política econômica e social de Estado, que era de resto hostilizada de modo mais ou menos aberto, conforme o momento, pelas antigas classes dominantes ligadas à agricultura de exportação.

Teve-se portanto, no pós-30, “crise de hegemonia", não obstante a implementação, por parte do aparelho de Estado, de uma política de industrialização. E foi essa situação peculiar que obrigou a burocracia estatal a implementar uma política bonapartista, com vistas a obter o apoio político das classes trabalhadoras. Os dois aspectos básicos dessa política foram, de um lado, o atendimento de 
aspirações difusas das classes trabalhadoras, como a criação de uma legislação fabril e o reconhecimento de direitos sociais a uma parte dos trabalhadores urbanos; de outro lado, a frustração do processo de conquista, por parte dos trabalhadores urbanos, de independência organizativa, frustração essa decorrente da criação de um sindicalismo rigidamente controlado pelo Estado e, por isso mesmo, sem força para atuar na construção de uma experiência partidária de massa de caráter independente.

Se fizemos essa apresentação - por certo, resumida - dos contornos da “crise de hegemonia” do período 1930-1964, foi porque não se poderia explicar as sucessivas metamorfoses da cidadania política nesse período se não se levasse em contas as condições históricas gerais em que transcorreu a marcha - seja para a frente, seja para trás - dos direitos políticos. A rigor, a cidadania política passou, no período 1930-1964, por três estágios: o da crise, o da destruição e o da restauração da cidadania política. O primeiro estágio - que correspondeu a uma fase política específica do período de "crise de hegemonia" - começou com a Revolução de 1930 e se encerrou com a instauração do Estado Novo (1937). No âmbito de um estudo sobre a evolução da cidadania política no Brasil, a abordagem dessa fase política oferece especial interesse, já que se travava então, no terreno político, um debate sobre o próprio conceito de cidadania política, ou, mais especificamente, sobre a via institucional adequada para a concretização da cidadania política. Logo após a vitória do movimento político-militar de 1930, os segmentos da classe média urbana que haviam se envolvido - enquanto simpatizantes ou participantes ativos - no processo revolucionário tenderam a se dividir entre duas grandes propostas de (re)construção da cidadania política no país: a concretização da cidadania política liberal-burguesa "autêntica"; a instauração de um modelo alternativo de cidadania política, a cidadania “orgânica”. Ora, essa divergência se resolveu conciliatoriamente no Código eleitoral de 1932 e na Constituição federal de 1934, mediante a adoção de um sistema misto de representação política. Na Câmara dos Deputados, coexistiam desde então representantes eleitos pelo sufrágio universal ( $4 / 5$ do total) e representantes de classe ou profissionais, indicados por sindicatos ou associações de patrões e de empregados ( $1 / 5$ do total). Dentro desse sistema misto de representação política, a dimensão burguesa-liberal da cidadania política evoluía, graças à instauração da Justiça eleitoral, do voto secreto e da cabine indevassável, bem como por obra da introdução do voto feminino. Essa evolução compósita (reforma progressista da cidadania política "liberal", conjugada à introdução da representação de classe) da cidadania política esteve, na verdade, intimamente relacionada com a margem de liberdade e a força política conquistadas pela classe média na fase inicial da “crise de hegemonia". Após a revolução de 1930, nem as antigas classes dominantes tinham força política suficiente para preservar integralmente a antiga democracia "oligárquica" (devendo por isso submeter-se taticamente ao reformismo liberal de parte da classe média); nem a burguesia industrial tinha força política suficiente 
para se opor à representação de classe, firmemente defendida pelo movimento tenentista por meio de órgãos políticos, como o Clube 3 de Outubro.

Mesmo um análise superficial da conjuntura política de 1931-1934 nos permite concluir que a configuração assumida pela cidadania política nessa fase política era instável, e tendia a ser de curta duração. No biênio 1934-1935 a radicalização de segmentos da classe média urbana à esquerda e à direita, com o surgimento da ANL e da AIB, criou condições políticas para que a burocracia estatal civil e militar rompesse os seus laços de representação política direta com essa classe social, instaurando a ditadura estadonovista. Começava assim o segundo estágio da evolução da cidadania política no contexto da "crise de hegemonia" no seio do bloco das classes dominantes. Sob o Estado Novo (1937-1945), a burocracia estatal aproveitou eficazmente a cisão política no seio da classe média urbana para suprimir a cidadania política ("liberal” ou "orgânica"), e para aumentar, por essa via, a sua capacidade decisória. A burocracia estatal também prosseguiu, durante o Estado Novo, na sua política de criação ou consolidação de direitos sociais para os trabalhadores urbanos: codificação das leis trabalhistas e sociais na CLT, criação efetiva do salário mínimo etc. Ela pôs em prática, portanto, uma política compensatória, consistente em revogar direitos políticos, substituindoos por direitos sociais. Tal política, a que se agregaram os efeitos do controle estatal dos sindicatos, contribuiu para levar as classes trabalhadoras urbanas a prestar um apoio difuso ao governo. Esse apoio se mostrou especialmente importante num contexto político em que o aparelho de Estado reprimia as correntes liberal, de esquerda e de direita da classe média; e, ao mesmo tempo, implementava uma política de desenvolvimento que não contava com o apoio das antigas classes dominantes nem da nova classe dominante. A política compensatória da burocracia estadonovista não deveria portanto ser vista como uma "anomalia histórica", por implicar uma "antecipação" dos direitos sociais com relação aos direitos políticos. Essa suposta "antecipação" não era a expressão de uma falha cultural ou civilizacional, pois ela resultava, muito concretamente, do aumento da força política da burocracia estatal e do correlato enfraquecimento político da classe média urbana, tudo isso ocorrendo dentro de um contexto geral de "crise de hegemonia" no seio das classes dominantes. É de resto por isso que a representação de classe, defendida por várias correntes da classe média (como católicos, integralistas, fascistas, corporativistas puros), não foi implementada no Estado Novo, estando já constitucionalmente ausente do Parlamento (que aliás permaneceu fechado) e só figurando formalmente na organização do Conselho de Economia Nacional.

Com a queda do Estado Novo, começou em fins de 1945 o terceiro estágio da evolução da cidadania política no contexto da "crise de hegemonia" no seio do bloco das classes dominantes. Restauraram-se o regime democrático e a cidadania política. O prosseguimento da "crise de hegemonia" garantiu porém 
à burocracia estatal a força política necessária para que ela levasse adiante, sem o apoio explícito e sistemático de qualquer uma das classes dominantes, a implementação do seu projeto de industrialização e de integração política das classes trabalhadoras urbanas pela via da política social. Mas qual seria a cidadania política possível nesse contexto histórico? Das limitações constitucionais anteriormente impostas ao direito de voto, só restava na Carta de 1946, entre as grandes limitações, a interdição do voto do analfabeto. Quanto às condições de exercício do direito de voto, nesse período, restaurou-se a Justiça eleitoral (Constituição federal de 1946 e Código eleitoral de 1950) e introduziu-se a cédula única e oficial (leis de 1955 e de 1962). Houve entretanto algo de novo nesse período político, que fez com que ocorresse, entre 1946 e 1964, algo mais que uma mera restauração do estágio em que se encontrava a cidadania política na Primeira República. Como conseqüência da intensificação dos processos de urbanização e de industrialização, no pós-30, o eleitorado das grandes cidades, tendencialmente assalariado e desvinculado de relações de dependência pessoal, viu-se bastante ampliado (13). Essa evolução do universo eleitoral - condicionada por um certo desenvolvimento do sistema econômico - provocou um remanejamento interno no campo das limitações práticas do exercício do direito de voto. Diminiu - embora não se tenha liquidado - a importância relativa do controle coronelístico do voto das populações rurais. A presença da Justiça eleitoral impôs alguma limitação à influência dos chefes políticos locais na organização e condução do processo eleitoral nessas áreas. Correlatamente, aumentou a importância do clientelismo urbano (isto é, da troca de favores por votos) no processo eleitoral. É importante assinalar que a burocracia estatal se mostrou apta a assimilar tais mudanças. De um lado, ela dispunha das condições político-institucionais necessárias à sua própria conversão em agente do clientelismo urbano e à colocação dessa prática eleitoral a serviço do seu projeto de desenvolvimento capitalista. E foi de fato o que fez essa categoria social, ao criar um partido popular urbano e trabalhista fundamentalmente controlado pelo aparelho de Estado: o PTB. De outro lado, ela poderia contar com a desesperança dos chefes políticos locais quanto à utilização do controle eleitoral da área rural como arma eficaz para a restauração da hegemonia política do capital mercantil-exportador, já que diminuía continuamente a importância relativa do eleitorado dos distritos rurais, politicamente controlado pelos coronéis. Nessas novas condições, só a introdução do voto do analfabeto poderia servir como arma política para as antigas classes dominantes: caso os analfabetos passassem a votar, tais classes sociais poderiam, pelo menos, jogar o peso do eleitor rural analfabeto contra o peso do eleitorado urbano alfabetizado. $\mathrm{O}$ fato de que as antigas classes dominantes jamais tivessem se lançado na defesa do voto do analfabeto, e de que tivessem se inclinado antes a temê-lo pelo seu pretenso potencial revolucionário, indica o quão grande era o seu declínio político e quão profunda a sua incapacidade de lutar pela hegemonia política. Foi por isso, de resto, que puderam chegar a imaginar, já em desespero 
de causa, que o golpe militar de 1964 poderia ser o instrumento de uma "restauração oligárquica”. A configuração assumida pela cidadania política no novo período democrático (1945-1964) se correlacionava portanto com a persistência do poderio bonapartista da burocracia estatal após a queda do Estado Novo, pois essa categoria social logrou fazer funcionar a seu favor (ou, mais especificamente, a favor do seu projeto de desenvolvimento capitalista) o clientelismo urbano; bem como colocar a seu serviço (isto é, a serviço de tal projeto) os chefes políticos locais, que já não tinham esperanças de que ocorresse uma "restauração oligárquica" pelas urnas.

Avaliando-se historicamente os dois ciclos de cidadania política (o de 18891930 e o de 1930-1964), deve-se concluir que, de um período a outro, houve uma evolução, dentro dos limites impostos à participação política pelo modelo capitalista de sociedade. Na passagem da submissão às práticas coronelísticas ao enquadramento em práticas clientelísticas, a consciência popular realizou um salto qualitativo, que traduziu o deslocamento de um universo ideológico feudal para um universo ideológico burguês. Ou, noutras palavras, passou-se, aí, de um comportamento político constrangido e cerceado pelo dever de lealdade pessoal a um comportamento político livre, que traduzia a visão do voto como mercadoria, a ser utilizado em função das vantagens pessoais proporcionadas pela escolha. $\mathrm{O}$ avanço do clientelismo indicou de resto, indiretamente, que no segundo período em questão a transição para o capitalismo estava chegando a seu termo. E isto porque, diferentemente do coronelismo, as práticas clientelísticas são o mecanismo de limitação concreta do exercício do direito de voto que mais se expandem nas sociedades capitalistas (14).

\section{O regime militar}

\section{e o confinamento da cidadania política}

Em fins da década de 1950 estava praticamente integralizada a transição para o capitalismo no Brasil, significando concretamente que a importância econômica do setor capitalista (a indústria) ultrapassava a de um setor ainda basicamente pré-capitalista (a agricultura). Em 1960, a agricultura respondia por $22 \%$ do $\mathrm{PNB}$, enquanto a indústria já respondia por $33 \%$. Estava assim objetivamente colocada a possibilidade de que o setor agrícola viria a se integrar ao desenvolvimento capitalista, enquanto mercado consumidor de meios de produção e de insumos gerados pela indústria; integração essa que repercutiria nas relações econômico-sociais vigentes na agricultura, determinando a difusão do arrendamento de terras e do trabalho assalariado rural. Nesse contexto econômico, colocou-se um novo dilema para as forças políticas envolvidas objetivamente no processo de industrialização. Dever-se-ia romper o compromisso histórico com a grande propriedade fundiária e promover uma reforma agrária distributiva, capaz de engendrar uma agricultura familiar que, com o 
apoio creditício do Estado, propiciaria um mercado de consumo para os bens leves e para os meios de produção propiciados pela indústria? Ou, inversamente, dever-se-ia dar prosseguimento à industrialização sem ruptura do compromisso histórico com o latifúndio e com apoio nalguns fatores alternativos de dinamização do processo de industrialização, como a entrada de capital estrangeiro no setor industrial/bancário ou os efeitos dinâmicos das relações econômicas intersetoriais (a indústria comprando da indústria, a indústria requisitando serviços, os serviços comprando da indústria e consumindo outros serviços)?

Esse dilema, como se sabe, cindiu politicamente a sociedade brasileira. Os defensores da segunda alternativa, politicamente representados pelo alto comando das Forças Armadas e guarnecidos de um apoio de massa fornecido por uma parte considerável da classe média urbana, derrotaram os defensores da primeira alternativa pelo golpe de Estado de 1964. Sublinhe-se entretanto que a intervenção político-militar de 1964 ocorreu num quadro histórico bastante diferente daquele da Revolução de 1930 e da redemocratização de 1946. Nesses momentos históricos anteriores, a burguesia industrial estrangeira só encarava os países periféricos como mercado de consumo para as suas mercadorias, pois os efeitos da crise mundial de 1929 ainda se faziam sentir mesmo nos países centrais. Já a partir de meados da década de 1950, a burguesia industrial dos países capitalistas centrais foi progressivamente redefinindo a sua posição, passando a encarar os países capitalistas periféricos como campo para investimentos diretos. Assim se viram solapados o solo histórico da "crise de hegemonia" anterior, o poderio bonapartista da burocracia estatal e as políticas de industrialização antecipatórias, prioritariamente comprometidas com o ideal da soberania nacional.

Foi nesse novo contexto histórico, marcado pelo fim da transição para o capitalismo no Brasil e pelo surgimento do interesse do capital estrangeiro em se internalizar nas economias periféricas, que se situou o regime militar. Interagindo com tal contexto, o grupo militar e a burocracia estatal solucionariam, mediante uma nova política econômica e social, a "crise de hegemonia", instaurando no seio do bloco das classes dominantes a hegemonia política de um subsistema de interesses econômicos capitalistas. Tal subsistema correspondia a uma rede de interesses monopolistas, que articulava o capital monopolista estrangeiro, o capital monopolista interno e o capital monopolista estatal, com a preponderância dos interesses do grande capital bancário nacional (15). Ao longo de 20 anos, o regime militar promoveria persistentemente a concentração e a centralização do capital industrial e do capital bancário, só secundariamente levando em conta os interesses da agricultura pré-capitalista e do médio capital (e isso, sobretudo no caso de esse capital se integrar economicamente ao grande capital, como fornecedor de insumos). 
Passemos agora à análise da configuração assumida pela cidadania política no contexto histórico do regime militar. Muitos cientistas políticos tenderam a sustentar que, tendo o regime militar um caráter ditatorial, só poderia ter ocorrido, correlatamente à sua implantação, a supressão absoluta da cidadania política; isto é, algo similar ao que ocorrera, antes, com a implantação da ditadura estadonovista. Na verdade, o tratamento dado à cidadania política pelo regime militar foi mais complexo que isso. O grupo militar, tendo assumido o controle do aparelho de Estado, buscou, não a supressão absoluta, mas o confinamento da cidadania política. E se o fez, foi porque julgou conveniente, por razões que abordaremos a seguir, encenar a existência da cidadania política e da representação política. Relembre-se que o regime militar reafirmou o direito de voto e manteve pelo menos as eleições para os Legislativos, ainda que sujeitas por vezes a adiamentos. Preocupou-se em manter aberto o Parlamento, a despeito de ter decretado, por vezes, o recesso parlamentar fora de prazo. Ao mesmo tempo, o grupo militar procurou implementar uma estratégia de limitação dos efeitos políticos práticos do exercício do direito de voto. Os detentores de cargos executivos foram escolhidos predominantemente por meio de eleições indiretas ou nomeações. A liberdade partidária foi limitada pela imposição autoritária de um bipartidarismo que era apenas uma caricatura dos sistemas partidários anglosaxões (tal bipartidarismo durou até o início da crise do regime militar em 1979). Estreitou-se a margem de ação do Parlamento, reduzido a uma mera caixa de repercussão das decisões do executivo militarizado e punido sempre que tentou preencher um outro papel.

Do ponto de vista morfológico, a disposição do regime militar de, ao mesmo tempo, confinar a cidadania política e preservar a simbologia liberaldemocrática exprimiu-se pela conciliação de duas posturas jurídicas. De um lado, manifestou-se uma postura de conservação de uma forma constitucionalista para o regime político. Tal postura se exprimiu mediante a edição de sucessivas emendas constitucionais, de uma carta constitucional (1967) e de uma lei com funções praticamente constitucionais (1969); todos esses dispositivos sendo apresentados como a cristalização - definitiva, até prova em contrário - da institucionalidade do regime político. De outro lado, delineou-se a postura de criação regular de uma legislação casuística, capaz de promover a adequação constante dos procedimentos de limitação da cidadania política à realidade política sempre em mutação: autorização da sublegenda, Lei Falcão, imposição do "senador biônico" etc. Desse modo conciliavam-se os pruridos constitucionalistas do grupo militar e a sua disposição de exercer cruamente o arbítrio. É importante sublinhar, neste ponto da análise, que esse misto de confinamento da cidadania política e de encenação liberal-democrática e constitucionalista não foi ocasional, nem se deveu a traços psicológicos individuais dos líderes do regime militar. Na verdade, essa política de dupla face esteve nesse período intimamente relacionada à 
configuração assumida pela hegemonia política no seio do bloco das classes dominantes. De um lado, o regime militar não poderia deixar intactos o alcance e o modo de organização do processo eleitoral, bem como a configuração do sistema partidário, sob pena de trazer de volta ao governo forças políticas que se oporiam à nova configuração da hegemonia política. De outro lado, deveria prestar culto à liberal-democracia, caso quisesse conservar a classe média urbana - ou pelo menos a parte mais importante dela. os chamados "formadores de opinião" - como a sua base social de apoio, e caso optasse, complementarmente, por uma postura conciliatória com relação às disposições políticas do capital monopolista estrangeiro e dos governos estrangeiros, sempre atentos com relação a possíveis degenerações nacionalistas das ditaduras militares periféricas. Podese portanto concluir que, para os militares que se apoderaram do aparelho de Estado em 1964, colocou-se, com muito mais força que para os instauradores do Estado Novo, a necessidade de manter em funcionamento mecanismos de legitimação política do regime militar, tanto no plano nacional quanto no plano internacional. A relação entre o estado da cidadania política, decorrente dessa necessidade, e a configuração da hegemonia política no seio do bloco das classes dominantes também pode, finalmente, ser comprovada por uma via negativa: os setores militares que propunham a supressão absoluta da cidadania política - ou seja, a chamada "linha dura" - eram ao mesmo tempo os setores que se opunham à preponderância política de um bloco monopolista no qual participasse o capital estrangeiro, e que defendiam a hegemonia política conjunta do capitalismo de Estado e da empresa privada nacional.

Em fins da década de 70 intensificaram-se as divergências de diferentes frações da classe capitalista com o regime militar. O médio capital industrial opunha-se ao caráter pró-monopolista da política econômica estatal; o capital monopolista nacional e o capital monopolista estrangeiro se insurgiram contra o excessivo poderio da tecnocracia na definição dos rumos da política econômica (poderio esse indevidamente qualificado por certos capitalistas dissidentes e pela imprensa liberal em termos de um nível inaceitável de "estatização" da vida econômica). A tais divergências articularam-se os efeitos políticos da resistência movida pelas classes trabalhadoras à política de contenção dos salários implementada pelo regime militar. Delineava-se assim a crise do regime militar, que resultou da oposição a múltiplas dimensões da sua política econômica e social mas não se configuraria como o coroamento de uma supostamente préexistente "crise de hegemonia" no seio do bloco das classes dominantes. A longa crise do regime militar (cuja duração foi de aproximadamente uma década) chegou a seu termo com a aprovação da Constituição federal de 1988 e com a realização de uma eleição direta para a presidência da República. É quase unânime, entre os cientistas políticos brasileiros, a opinião de que, com a Constituição federal de 1988, a cidadania política chegara a seu ápice na história brasileira, pelo menos no plano da declaração de direitos políticos. E isto porque não mais 
subsistia a proibição do voto do analfabeto; além de que se instaurou uma relativa liberdade de organização partidária.

Não se poderia ter chegado a esse resultado institucional se, desde os fins da década de 70, as classes trabalhadoras não tivessem oposto uma forte resistência política ao regime militar. Com a aprovação da Constituição federal de 1988, abriu-se a possibilidade de as classes trabalhadoras desenvolverem, num quadro histórico em que foi restaurada a eficácia política prática do exercício do direito de voto, experiências partidárias de caráter massivo e independente. Porém, ao especularmos sobre as possibilidades de gozo efetivo da cidadania política, devemos ser fiéis ao nosso método, e atentar para a configuração da hegemonia política no quadro da democracia presidencialista pós-1988. Os governos civis da década de 90 concretizaram uma nova hegemonia política (cuja possibilidade só se desenharia nos últimos anos do chamado "governo de transição", na segunda fase do governo Sarney): a do capital financeiro internacional, que desmantelou o setor público e desorganizou a burguesia de Estado mediante o programa de privatizações; confrontou-se com o grande capital bancário nacional, procurando minar a sua posição ainda forte; levou parte da burguesia industrial interna à falência; e subjugou, pelo crédito e pela taxa de juros, até mesmo os setores mais dinâmicos da grande agricultura. Como as classes trabalhadoras, também o capital financeiro internacional está presente - por intermédio de seus representantes políticos internos - na cena política. E também ele procura fazer funcionar em seu proveito a cidadania política, contando para tanto com a prática em escala mais ampla (e por vias mais sofisticadas) do clientelismo eleitoral em suas várias versões: o clientelismo privado (promovido com apoio em recursos empresariais, internos ou estrangeiros); o clientelismo estatal (promovido pela implementação de políticas imediatistas, destinadas a arregimentar votos a partir de obras públicas de interesse paroquial); o clientelismo público-privado (concessão de benefícios pessoais, mas com recursos financeiros desviados do Estado). Vivemos portanto num momento histórico em que pelo menos duas forças políticas distintas disputam a possibilidade de aproveitamento dos direitos políticos instaurados em 1988. De um lado, as classes trabalhadoras procurando transformá-los em plataforma para o desenvolvimento e a expansão de uma política independente de massa. De outro, o capital financeiro internacional procurando reverter a seu favor os direitos políticos restaurados por obra da resistência das classes populares ao regime militar, enquadrando o seu exercício em práticas clientelísticas de caráter cada vez mais complexo e sofisticado, como é de se esperar de qualquer sociedade capitalista.

\section{A instabilidade da cidadania política no Brasil republicano}

Procuramos, neste texto, caracterizar as diversas limitações impostas à cidadania política nos diferentes períodos políticos por que passou o Brasil 
republicano. E, mais ainda, procuramos relacionar tais limitações com a configuração assumida pela hegemonia política no seio das classes dominantes e com o alcance das lutas populares travadas no contexto do exercício dessa hegemonia. Para finalizar este ensaio, devemos abordar brevemente um fato sobejamente conhecido: a alternância de períodos democráticos e de períodos ditatoriais ao longo de nossa (curta) história republicana. Relembremos, em termos sintéticos, essa alternância:

- democracia “oligárquica” entre 1894 e 1930;

- período de transição, entre 1930 e 1937;

- ditadura estadonovista, de 1937 a 1945;

- democracia nacional-populista, de 1946 a 1964;

- ditadura militar, de 1964 a 1984;

- novo regime democrático-constitucional, a partir de 1988.

Como explicar essa instabilidade da cidadania política no Brasil ao longo de um período de pouco mais de cem anos, se nos países da Europa do Norte, na Inglaterra e nos EUA (neste, pelo menos desde a Guerra de Secessão), ela permaneceu estável por períodos bem mais longos? Para alguns cientistas políticos, brasileiros ou brasilianistas, esse déficit de estabilidade política poderia ser explicado pela tendência militarista inerente ao Brasil republicano: as Forças Armadas possuiriam, aqui, uma inclinação congênita a intervir no processo político. A nosso ver, essa é mais uma explicação que merece ser questionada. Nelson Werneck Sodré objetou corretamente a esse tipo de formulação, advertindo tratar-se de tese formalista se não se faz acompanhar de uma análise do conteúdo e do significado de cada intervenção militar no processo político. Ora, quando se analisa tais conteúdos e significados, percebe-se o quanto é simplificador igualizar todas as intervenções políticas do grupo militar sob a rubrica do "militarismo". Como é possível, por exemplo, conferir eqüivalência teórica e política à participação militar na Abolição, na Proclamação da República e no golpe de Estado antivarguista de 1954, à Revolução de 1930 e ao ensaio de golpe de Estado contra Kubitschek em 1955, à derrubada do Estado Novo e ao golpe militar de 1964?

A nosso ver, é conveniente relacionar a instabilidade da cidadania política no Brasil republicano, não com um suposto militarismo peculiar à sociedade brasileira, mas - ainda uma vez, conforme o método de análise já exposto - com a configuração assumida pelo processo de desenvolvimento do capitalismo no Brasil e com a natureza dos processos de redefinição da hegemonia política no seio das classes dominantes, peculiares a tal processo. $\mathrm{O}$ desenvolvimento do capitalismo no Brasil (seja na fase de transição, seja na fase de reprodução ampliada) configura-se como um desenvolvimento capitalista retardatário (pois 
o Brasil iniciou esse processo cem anos - ou mais - após os países capitalistas centrais) e dependente (pois o Brasil incorporou tecnologia industrial gerada anteriormente pelos países capitalistas centrais). Ora, a outra face do caráter retardatário e dependente do desenvolvimento capitalista no Brasil é o seu caráter acelerado: como o Brasil incorporou, mediante importações, tecnologia industrial já pronta, ele pode andar mais rápido, passando em tempo histórico bem menos longo da fase de transição à fase de reprodução ampliada.

O caráter acelerado do desenvolvimento capitalista no Brasil implicou, por sua vez, redefinições mais rápidas da hegemonia política no seio das classes dominantes, já que esse desenvolvimento supunha sucessivamente: a chegada do capital mercantil ao seu ápice e, a seguir, o seu declínio; a ascensão progressiva da burguesia industrial; a diferenciação do capital em capital monopolista e médio capital (tal desenvolvimento pode, finalmente, abranger a constituição - por uma dentre algumas das vias possíveis - do capital financeiro).

Mas como se processou politicamente a redefinição da hegemonia política no seio do bloco das classes dominantes? Nicos Poulantzas sustenta, em vários trabalhos (16), que tal redefinição supõe, em geral, uma ruptura institucional. Ou seja: para instaurar a sua hegemonia política, uma nova fração ou classe dominante deveria desalojar a fração ou classe, antes hegemônica, do conjunto do aparelho de Estado (administração, aparato judiciário, Forças Armadas, polícia etc.), e não apenas ganhar as eleições (isto é, apoderar-se tão somente do governo stricto sensu). Daí a freqüência dos golpes militares e das revoluções populares nas sociedades capitalistas. Esses movimentos têm funcionado, muitas vezes, como a alavanca de processos de redefinição da hegemonia política no seio das classes dominantes, embora alguns deles apresentassem - ainda uma vez nos termos de Gramsci - um caráter inorgânico.

Ligando todos os elos de nossa cadeia argumentativa, poderemos finalmente propor de modo formal e sistemático a hipótese de que a instabilidade da cidadania política no Brasil republicano se deveu em última instância ao caráter retardatário, dependente e conseqüentemente acelerado do processo de desenvolvimento do capitalismo no país; e, em primeira instância, à rapidez com que ocorreram sucessivas redefinições da hegemonia política no seio das classes dominantes (redefinições essas responsáveis por rápidas mudanças de regime político). Evidentemente, o teste decisivo para essa hipótese explicativa consistiria na apresentação exaustiva de evidências acerca da ocorrência, ou não, de vastos processos de "saneamento" do conjunto do aparelho de Estado a cada redefinição da orientação da política de Estado em função de novos interesses econômicos de fração ou classe dominante. Ainda que o material propiciado por inúmeras investigações de elevado gabarito científico sobre a história do Brasil republicano nos permita supor que algum "saneamento" do aparelho de Estado - de natureza e extensão variáveis - ocorreu em processos de ruptura institucional como a 
Proclamação da República, a Revolução de 1930 e o golpe militar de 1964, entendemos que a comprovação cabal da ocorrência de tais "saneamentos" exigiria uma nova pesquisa, complementar àquela cujos resultados apresentamos parcialmente neste texto. Diante dessa limitação expressa do processo de demonstração da hipótese explicativa em questão, é preferível que nossa menção às causas históricas da instabilidade da cidadania política no Brasil republicano seja provisoriamente encarada como um mero coroamento da exposição da linha teórica que orientou todas as nossas reflexões sobre a evolução da cidadania política no Brasil.

Notas

1 Ver José Murilo de Carvalho, Desenvolvimiento de la ciudadania en Brasil, Fondo de Cultura Económica, México, 1995.

2 Ver Luiz Carlos Bresser Pereira, Cidadania e res publica: a emergência dos direitos republicanos, In: Filosofia politica, nova série, v. l, Porto Alegre, ed. L\& PM, 1997.

3 Apresentamos anteriormente o nosso conceito de cidadania política no texto Cidadania e capitalismo (uma abordagem teórica), Coleção Documentos / Série Especial n. 8, Instituto de Estudos Avançados da USP, abr. 2000.

4 Ver Göran Therborn, The rule of capital and the rise of democracy, New Left Review, n. 103, maio/jun. 1977, Londres, New Left Books.

5 Ver Eric J. Hobsbawm, Mundos do trabalbo. Rio de Janeiro, Paz e Terra / São Paulo, 1987, capítulo 17, O operariado e os direitos humanos, p. 416.

6 Ver Luiz Carlos Bresser Pereira, Sociedade civil: sua democratização para a reforma do Estado. São Paulo, 1998 [mimeo.].

7 A análise de Marx sobre este ponto foi retomada por Hobsbawm, que aludiu à relação entre concentração/centralização do capital, concentração espacial da indústria e organização reivindicatória ou política das classes trabalhadoras. Ver Eric J. Hobsbawm, A era do capital. Rio de Janeiro, Paz e Terra, 1977, especialmente o capítulo 12, A cidade, a indústria, a classe trabalhadora.

8 Estamos aqui sugerindo a existência de uma correlação entre as variações do regime político e as variações da hegemonia política no seio do bloco no poder: mudando um, tende a mudar também a outra (o que está longe de significar - esclareça-se logo que a uma certa espécie de regime político corresponda necessariamente uma certa configuração da hegemonia política no seio do bloco no poder). Abordaremos mais sistematicamente esta questão na parte final deste texto.

9 Ao mencionarmos aqui os "avanços" ou "atrasos" da cidadania política no Brasil, estamos parafraseando outros autores. E, se o fazemos, não é porque consideremos conveniente a construção teórica de um percurso ideal da cidadania política na sociedade capitalista, percurso a partir do qual se poderia avaliar o estágio alcançado 
(elevado, embrionário, intermediário etc.) ou a situação vivida (normal, anômala etc.) pela cidadania política nas diferentes sociedades capitalistas (centrais, periféricas, etc.). Muito pelo contrário, pensamos que indicadores do "atraso" e do "avanço" da cidadania política - indicadores que podem ser fixados segundo um critério democrático radical (o da máxima participação política das massas, em termos de influência efetiva, ainda que marginal - sobre os agentes tomadores das macrodecisões) podem se combinar numa mesma sociedade capitalista, dificultando os diagnósticos unilaterais e simplificadores. Assim, por exemplo, numa democracia "avançada" como os EUA, os negros ainda estavam, no início da década de 1960, praticamente impedidos de votar (a despeito da inexistência de qualquer proscrição constitucional desse direito). De modo similar, na "modelar" democracia suíça, as mulheres só conquistaram o direito de voto no início da década de 1970. A lição a se tirar desses exemplos é a de que o mais importante, na análise política, é descobrir as causas históricas - a serem procuradas no terreno dos efeitos conjugados do padrão de desenvolvimento do capitalismo e da configuração da hegemonia política no seio do bloco no poder - do aparecimento de combinações aparentemente abstrusas, como as acima mencionadas.

10 A derrota do líder republicano radical Silva Jardim nas eleições de 1890 para a Assembléia Nacional Constituinte e, a seguir, a sua morte trágica na voragem do Vesúvio parecem simbolizar a rápida neutralização política da classe média liberal, envolvida na busca da cidadania política "autêntica", pelas "oligarquias".

11 Ver Virgínio Santa Rosa, Que foi o tenentismo, Rio de Janeiro, Civilização Brasileira, 1963 , p. 31.

12 A diferença entre burguesia compradora, burguesia interna e burguesia nacional foi abordada teoricamente por Nicos Poulantzas em Les classes sociales dans le capitalisme aujourd'hui. Paris, Editions du Seuil, 1974, especialmente p. 77-204.

13 Sobre as modificações porque passou sucessivamente o eleitorado brasileiro e a sua repercussão sobre a política partidária, ver Gláucio Ary Dillon Soares, Sociedade e política no Brasil. São Paulo, Ed. Difusão Européia do Livro, 1973, especialmente o capítulo III, A extensão da cidadania às classes trabalhadoras e as transformações do eleitorado brasileiro, no qual o autor apresenta boa quantidade de dados significativos sobre essa questão.

14 Sobre a importância do clientelismo - de tipo moderno, em oposição ao tipo tradicional - nas sociedades capitalistas avançadas, consultar o sugestivo artigo de Martine Droulers, Emprego público e clientelismo. Brasília, Sociedade e Estado, v. IV, n. 1, jan./jun. 1989.

15 Abordei a questão da preponderância do grande capital bancário no seio do subsistema de interesses monopolistas politicamente hegemônico a partir do golpe militar de 1964 no artigo Estado e classes sociais no capitalismo brasileiro dos anos 70/80, publicado nos Cadernos Primeira Versão n. 2, 1989, IFCH/Unicamp, Campinas; e republicado em Décio Saes, República do Capital/Capitalismo e processo poliotico no Brasil. São Paulo, Ed. Bomtempo, 2001.

16 Ver, por exemplo, Fascisme et dictatur., Paris, Ed. François Maspero, 1970, p. 356. 
RESUMO - NESTE artigo analisa-se as características fundamentais da cidadania política no Brasil republicano: o seu caráter limitado e a sua instabilidade. Tais características são aqui relacionadas, não com um fator cultural permanente, mas com fatores econômicos e políticos: o padrão de desenvolvimento do capitalismo, a luta pela hegemonia política e o conflito social.

ABSTRACT - IN THIS article is analyzed the fundamental characteristics of the political citizenship in Brazil since the establishment of the Republic in 1889: both its limited character and its instability. Such features are not related with a permanent cultural factor, but due to economical and political ones: the pattern of development of the capitalism, the struggle for political hegemony and the social conflict.

Décio Azevedo Marques de Saes é professor visitante do Instituto de Estudos Avançados da USP.

Neste artigo apresenta-se resultado parcial das atividades de pesquisa desenvolvidas pelo autor no Instituto de Estudos Avançados da USP, durante o período que se estendeu de agosto 1999 a julho 2001. Ao longo desse período, trabalhou no projeto "Capitalismo e cidadania no Brasil: um estudo sociológico sobre o padrão brasileiro de evolução da cidadania, da República Velha à Nova República (1891-1988)”. A tal projeto também se filia o texto Cidadania e capitalismo (uma abordagem teórica), anteriormente publicado pelo IEA na Coleção Documentos n. 8, Série Especial. Como este último apresenta de modo mais sistemático e detalhado o esquema teórico subjacente ao presente artigo, pode-se dizer que os dois textos são complementares. $\mathrm{O}$ texto aqui publicado corresponde, nas suas linhas gerais, à conferência proferida pelo autor a 18 de outubro de 2000, no Instituto de Estudos Avançados da USP. Foram de grande valia, para a preparação deste ensaio, as observações feitas pelos participantes do seminário e, em especial, os comentários lúcidos formulados pelos colegas Geraldo de Figueiredo Forbes e Francisco Pereira de Farias. Mas, segundo o autor, nenhuma dessas pessoas é minimamente responsável pelos erros aqui eventualmente cometidos. 